\title{
Hypertension in Indonesian air force pilots
}

\author{
Minarma Siagian
}

Department of Physiology, Faculty of Medicine, Universitas Indonesia, Jakarta, Indonesia

\begin{abstract}
Abstrak
Latar Belakang: Penelitian ini bertujuan untuk mengkaji hubungan antara bising yang disebabkan oleh pesawat terbang dengan tekanan darah.

Metode: Penelitian nested case-control dilakukan pada penerbang Angkatan Udara Republik Indonesia yang melakukan pemeriksaan fisik tahunan di Lembaga Kesehatan Penerbangan dan Ruang Angkasa (LAKESPRA) Saryanto tahun 2003 - 2008. Data yang diperoleh dari rekam medis berupa umur, jumlah jam terbang, jenis pesawat, kadar glukosa puasa dan kadar kholesterol darah, lingkaran pinggang, tinggi dan berat badan (Indeks Massa Tubuh), serta tekanan darah.
\end{abstract}

Hasil: Dari 549 penerbang, ada 49 yang hipertensif, dengan tekanan sistolik $\geq 140 \mathrm{mmHg}$ dan/atau tekanan diastolik $\geq$ $90 \mathrm{mmHg}$. Penerbang pesawat helikopter mempunyai risiko menderita hipertensi hampir 2 kali dibandingkan penerbang pesawat terbang biasa. Penerbang dengan jumlah jam terbang lebih dari 1400 jam mempunyai risiko menderita hipertensi lebih 2 kali dibandingkan penerbang dengan jumlah jam terbang $\leq 1400$ jam.

Kesimpulan: Jenis pesawat terbang, yang berkaitan dengan jenis bising yang terbangkit, mungkin merupakan faktor risiko hipertensi pada penerbang. Peningkatan jumlah jam terbang meningkatkan risiko hipertensi. (Med J Indones 2012;21:38-43)

\begin{abstract}
Background: To investigate the association between aircraft noise and blood pressure.

Methods: A nested case-control study was conducted on Indonesian Air Force pilots doing annual medical check-ups at the Saryanto Institute for Aviation and Aerospace Health (LAKESPRA) from 2003 - 2008. The data extracted from medical records were age, total flight hours, type of aircraft, fasting blood glucose and cholesterol levels, waist circumference, height and weight (Body Mass Index), and blood pressure.
\end{abstract}

Results: There were 549 pilots, 49 were found to be hypertensive, with SBP $\geq 140 \mathrm{mmHg}$ and/or DBP $\geq 90 \mathrm{mmHg}$. Helicopters pilots were at an almost 2 fold risk of hypertension compared to pilots of the fixed wing aircrafts. Pilots with more than 1400 hours of flight had more than 2 fold risk of being hypertensive compared to those with 1400 flight hours or less.

Conclusion: The type of aircraft, which is related to the noise generated, may be a risk factor for developing hypertension in pilots. Increased total flight hours also increased the risk of hypertension. (Med J Indones 2012;21:38-43)

Keywords: Aircraft noise, hypertension, pilots

Noise is suspected to have detrimental effects on human health. Epidemiological and laboratory studies demonstrated that noise have both temporary and permanent effects on human physiology. ${ }^{1-4}$ It has been linked with various physiological effects. ${ }^{1-5}$ These effects may be aural, such as temporary hearing impairment to permanent noise-induced hearing loss (NIHL), aural pain, speech interference, or non-aural, such as startle and defense reactions, annoyance responses, sleep disturbance, cardiovascular effects, performance reduction, gastrointestinal disturbances and immunologic impairment. ${ }^{2-6}$

A few studies reported an increase in the prevalence of hypertension in people living around busy airports, but the relationship has been rarely investigated. ${ }^{6,7}$ Surveys conducted around Schiphol Airport in the Netherlands showed a relationship between aircraft noise and increased visits to general practitioners, health problems and increased use of cardiovascular medications, including antihypertensives. ${ }^{7,8}$ Another survey in 8 villages surrounding an airport found that there was an increased prevalence of hypertension in the population aged 34 to 64 years. Increased blood pressure was also reported due to low flying military aircrafts and in rats exposed to recorded aircraft noise. ${ }^{7,8}$

Pilots are constantly exposed to aircraft noise that can reach $90-120 \mathrm{~dB}$. This exposure to aircraft noise has auditory and non-auditory effects on the human body, including the cardiovascular system. A few studies have indicated that chronic noise exposure is a risk factor for blood hypertension in pilots exposed to high noise levels and the possibility of links between hearing impairment and hypertension. ${ }^{9-11}$ There was a higher prevalence of hypertension, nearly always diastolic, and ECG abnormalities in the group of pilots of turboprop aircraft compared to jet plane pilots. ${ }^{11,12}$ Therefore, this study aimed to investigate the association between noise, specifically aircraft noise, on systolic and diastolic blood pressure. 


\section{METHODS}

This is a nested case-control study of Indonesian Air Force pilots attending annual medical check-ups at the Saryanto Institute for Aviation and Aerospace Health (LAKESPRA) from 2003 - 2008. These annual medical check-ups are mandatory for certification of fit to fly for the pilots. Ethical clearance was obtained from the Ethics Committee of the Faculty of Medicine, Universitas Indonesia.

\section{Cases and controls}

The inclusion criteria for the cases and controls were male air crew of the Indonesian Air Force. The exclusion criteria were those with incomplete medical check-up data. Cases were pilots diagnosed with hypertension according to the JNC 7 criteria from medical checkup results from January 2003 up to September 2008. ${ }^{13}$ Controls were those never known to suffer from hypertension based on medical check-up data. The criteria for hypertension: systolic blood pressure (SBP) $140 \mathrm{mmHg}$ or more, or diastolic blood pressure (DBP) $90 \mathrm{mmHg}$ or more.

\section{Data collection}

The data extracted from the medical records of these annual medical check-ups were age on diagnosis, age at starting work, year of entering work, rank, average flight hours per year, type of aircraft, total flight hours, and duration of work. Besides blood pressure, other clinical and laboratory data, such as waist circumference, body mass index (BMI) calculated from height and weight, resting pulse rate, pulse pressure, fasting blood glucose, and cholesterol levels were also obtained. For numerical data, means and standard deviations (SDs) were calculated and tabulated.

The specific variables for pilots that were analyzed as risk factors for this study were the same as previous study with slight modifications, i.e. the type of aircraft, (fixed wing planes or helicopters), the length of employment ( $2-10$, and $11-25$ years), age on diagnosis (23-29, $30-39$, and 40-48 years), age at starting work (19-22, and $23-26$ years), rank (first officers that are second lieutenant to captain and middle-ranked officers that are major until colonel), total flight hours (147-1400, and 1401-11.125 hours), annual average flight hours (29-299, and 300-622 hours/year), and year of starting work (year $1980-1990$ and $1991-2003){ }^{12}$

Further, data that may be related to hypertension were also collected, i.e. fasting blood glucose level (less than or equal to 126 , and greater than $126 \mathrm{mg} / \mathrm{dL}$ ), blood cholesterol level (less than or equal to 200, and more than $200 \mathrm{mg} / \mathrm{dL})$, BMI (18.00-22.99, 23.00-24.99, and $\left.25.00-39.00 \mathrm{~kg} / \mathrm{m}^{2}\right),{ }^{14}$ waist circumference (normal $\leq 90$, and high $>90 \mathrm{~cm})$, resting pulse rate $(50-80$, and $81-101 /$ minute), resting pulse pressure (10-40, and 41-
$90 \mathrm{mmHg}$ ). Grouping of variables were based on the ROC curves. ${ }^{12}$

All the data collected were checked manually for completeness and consistency before data processing. Verification of the data was done visually for any errors.

\section{Data analysis}

Statistical analyses were done using STATA 9.0 software. ${ }^{15}$ The risk factors were examined whether they were potential confounders and/or effect modifiers. Unconditional logistic regression analysis was used to determine the confounding effects and the risk factors for hypertension. ${ }^{16} \mathrm{~A}$ risk factor was considered to be a potential confounder if in the univariate test it had a $P$-value of $<0.25$, and would be included in the multivariate model along with all known risk factors for hypertension. ${ }^{17}$ Confounders were estimated by the method of maximum likelihood. Ninety-five percent confidence intervals were based on the standard error of coefficient estimates. Relative risks represented by odds ratios $(\mathrm{OR})$ were estimated by maximum likelihood.

\section{RESULTS}

There were 539 pilots with complete medical records, with 406 pilots of fixed-wing aircraft (transport and fighter jets) and 133 helicopter pilots. Of these pilots, 49 were diagnosed as hypertensive between the years 2003 to 2008, with $\mathrm{SBP} \geq 140 \mathrm{mmHg}$ or $\mathrm{DBP} \geq 90$ $\mathrm{mmHg}$. Age ranged from 23 to 48 years.

Table 1 showed that the risk of hypertension was found to be increasing with age. Those in the $40-48$ years age group had almost a 1.7 fold risk of hypertension compared to pilots of less than 30 years. Pilots who started work at a later age were also found to be at a 1.6 fold risk of developing hypertension. Middle-ranked officers were 1.5 times more likely to be hypertensive.

Helicopters pilots were at a 1.9 fold risk of hypertension compared to the fixed wing aircraft pilots. Pilots with more than 1400 total flight hours were 2 times more likely to have hypertension compared to those with less than 1400 total flight hours. Longer duration of work, more than 11 years, was also found to be at a 1.6 fold risk for hypertension compared to those working for less than 11 years. But the average flight hours per year was similarly distributed between those with hypertension and those with normal blood pressure.

From table 2 on clinical and laboratory findings, it was shown that waist circumference, BMI, fasting blood glucose and cholesterol level was similarly distributed among pilots with hypertension and those with normal blood pressure. But pilots with a resting pulse rate of more than 81 beats/minute or more were found to be 2.4 
times to be hypertensive, compared to those with less than 80 beats/minute. Pilots with pulse pressures of 41 $\mathrm{mmHg}$ or more had a 2.5 fold of being hypertensive.

Table 3 showed that the dominant risk factors related to hypertension were total flight hours, type of aircraft, resting pulse rate, and pulse pressure. Pilots with more than 1400 total flight hours were almost 2 times more likely to develop hypertension compared to pilots with 1400 flight hours or less. Helicopter pilots were found to be almost 2 times more likely to develop hypertension, with $p<0.05$, compared to fixed wing pilots. Pilots with a resting pulse rate of more than 80 beats/minute were more than 2 times likely to be at risk of hypertension, $p$ $<0.05$. A pulse pressure of more than $40 \mathrm{mmHg}$ was a risk of almost 2.5 fold for hypertension, $\mathrm{p}<0.05$.

Table 1. Bivariate analysis on some demographic characteristics as the risk factor of hypertension in pilots

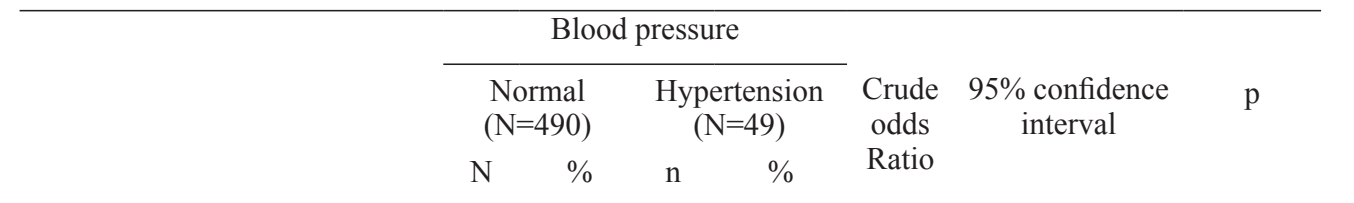

Age on diagnosed

23-29 years
30-39 years
40-48 years

Age of starting work

$$
\begin{aligned}
& \text { 19-22 years } \\
& \text { 23-26 years }
\end{aligned}
$$

\section{Year of entering work}

$$
\text { 1980-1990 }
$$$$
\text { 1991-2000 }
$$

\section{Rank}

$$
\text { Low-ranked officers }
$$

Middle-ranked officers

\section{Average flight hours per year}

$$
\text { 29-299 jam }
$$$$
\text { 300-622 jam }
$$

\section{Type of aircraft}

Fixed wings

Helicopters

\section{Total flight hours}

147-1400 hours
1401-11125 hours
Duration of work
2-10 years
11-25 years

14

28.57

1.00 Reference

$\begin{array}{llllll}183 & 37.35 & 25 & 51.02 & 1.68 & 1.92-15.10\end{array}$

0.826

0.139

$318 \quad 64.90 \quad 26$

$172 \quad 35.10 \quad 23$

53.06

1.00 Reference

$46.94 \quad 1.64 \quad 0.91-2.95$

0.103

$11122.65 \quad 18$

$379 \quad 77.35 \quad 31$

36.73

63.27

1.00 Reference

$0.50 \quad 0.27-0.94$

0.030

$\begin{array}{llllll}290 & 59.18 & 24 & 48.98 & 1.00 & \text { Reference }\end{array}$

$\begin{array}{llllll}445 & 90.82 & 43 & 87.76 & 1.00 & \text { Reference } \\ 45 & 9.18 & 6 & 12.24 & 1.38 & 0.56-3.42\end{array}$

$\begin{array}{llllll}375 & 76.53 & 31 & 63.27 & 1.00 & \text { Reference } \\ 115 & 23.47 & 18 & 36.73 & 1.89 & 1.02-3.51\end{array}$

0.043

$231 \quad 47.14 \quad 15$

$30.61 \quad 1.00$ Reference

$\begin{array}{llllll}259 & 52.86 & 34 & 69.39 & 2.02 & 1.07-3.80\end{array}$

0.029

0.110 
Table 2. Bivariate analysis on some physiological and laboratory findings as the risk factor of hypertension in pilots

\begin{tabular}{|c|c|c|c|c|c|c|c|}
\hline & \multicolumn{4}{|c|}{ Blood pressure } & \multirow{3}{*}{$\begin{array}{l}\text { Crude } \\
\text { odds } \\
\text { ratio }\end{array}$} & \multirow{3}{*}{$\begin{array}{c}95 \% \text { confidence } \\
\text { interval }\end{array}$} & \multirow{3}{*}{$\mathrm{p}$} \\
\hline & \multicolumn{2}{|c|}{$\begin{array}{l}\text { Normal } \\
(\mathrm{N}=490)\end{array}$} & \multicolumn{2}{|c|}{$\begin{array}{l}\text { Hypertension } \\
\quad(\mathrm{N}=49)\end{array}$} & & & \\
\hline & $\mathrm{n}$ & $\%$ & $\mathrm{n}$ & $\%$ & & & \\
\hline \multicolumn{8}{|l|}{ Waist circumference } \\
\hline $64-90$ & 449 & 91.63 & 44 & 89.80 & 1.00 & Reference & \\
\hline $90-112$ & 41 & 8.37 & 5 & 10.20 & 1.24 & $0.47-3.31$ & 0.661 \\
\hline Body Mass Index (BI & & & & & & & \\
\hline $18.00-22.99 \mathrm{~kg} / \mathrm{m}^{2}$ & 80 & 16.33 & 5 & 10.20 & 1.00 & Reference & \\
\hline $23.00-24.99 \mathrm{~kg} / \mathrm{m}^{2}$ & 140 & 28.57 & 15 & 30.61 & 1.71 & $0.60-4.89$ & 0.314 \\
\hline $25.00-39.00 \mathrm{~kg} / \mathrm{m}^{2}$ & 270 & 55.10 & 29 & 59.18 & 1.72 & $0.64-4.58$ & 0.280 \\
\hline \multicolumn{8}{|l|}{ Resting pulse rate } \\
\hline $50-80$ beats/minute & 358 & 73.06 & 26 & 53.06 & 1.00 & Reference & \\
\hline $81-101$ beats/minute & 132 & 26.94 & 23 & 46.94 & 2.40 & $1.32-4.35$ & 0.004 \\
\hline Pulse pressure & & & & & & & \\
\hline $10-40 \mathrm{mmHg}$ & 391 & 79.80 & 30 & 48.98 & 1.00 & Reference & \\
\hline $41-90 \mathrm{mmHg}$ & 99 & 20.20 & 19 & 38.78 & 2.50 & $1.35-4.63$ & 0.004 \\
\hline \multicolumn{8}{|c|}{ Fasting blood glucose level } \\
\hline $70-125 \mathrm{mg} \%$ & 486 & 99.18 & 48 & 97.96 & 1.00 & Reference & \\
\hline $126-290 \mathrm{mg} \%$ & 4 & 0.82 & 1 & 2.04 & 2.53 & $0.28-23.10$ & 0.410 \\
\hline \multicolumn{8}{|l|}{ Blood cholesterol level } \\
\hline $90-199$ mg\% & 244 & 49.80 & 23 & 46.94 & 1.00 & Reference & \\
\hline $200-310 \mathrm{mg} \%$ & 246 & 50.20 & 26 & 53.06 & 1.12 & $0.62-2.02$ & 0.703 \\
\hline
\end{tabular}

Table 3. The dominant risk factors related to hypertension in pilots

\begin{tabular}{|c|c|c|c|c|c|c|c|}
\hline & \multicolumn{4}{|c|}{ Blood pressure } & \multirow{3}{*}{$\begin{array}{c}\text { Adjusted } \\
\text { odds } \\
\text { ratio* }\end{array}$} & \multirow{3}{*}{$\begin{array}{c}95 \% \text { confidence } \\
\text { interval }\end{array}$} & \multirow{3}{*}{$\mathrm{p}$} \\
\hline & \multicolumn{2}{|c|}{$\begin{array}{l}\text { Normal } \\
(\mathrm{N}=490)\end{array}$} & \multicolumn{2}{|c|}{$\begin{array}{l}\text { Hypertension } \\
\qquad(\mathrm{N}=49)\end{array}$} & & & \\
\hline & $\mathrm{n}$ & $\%$ & $\mathrm{n}$ & $\%$ & & & \\
\hline \multicolumn{8}{|l|}{ Total flight hours } \\
\hline $147-1400$ hours & 231 & 47.14 & 15 & 30.61 & 1.00 & Reference & \\
\hline $1401-11125$ hours & 259 & 52.86 & 34 & 69.39 & 1.99 & $0.99-3.80$ & 0.054 \\
\hline \multicolumn{8}{|l|}{ Type of aircraft } \\
\hline Fixed wings & 375 & 76.53 & 31 & 63.27 & 1.00 & Reference & \\
\hline Helicopters & 115 & 23.47 & 18 & 36.73 & 1.99 & $1.05-3.72$ & 0.034 \\
\hline \multicolumn{8}{|l|}{ Resting pulse rate } \\
\hline $50-80$ beats/minute & 358 & 73.06 & 26 & 53.06 & 1.00 & Reference & \\
\hline $81-101$ beats/minute & 132 & 26.94 & 23 & 46.94 & 2.08 & $1.15-3.89$ & 0.021 \\
\hline \multicolumn{8}{|l|}{ Pulse pressure } \\
\hline $10-40 \mathrm{mmHg}$ & 391 & 79.80 & 30 & 48.98 & 1.00 & Reference & \\
\hline $41-90 \mathrm{mmHg}$ & 99 & 20.20 & 19 & 38.78 & 2.31 & $1.23-4.34$ & 0.009 \\
\hline
\end{tabular}

*Adjusted odd ratios adjusted to other risk factors on this table

\section{DISCUSSION}

In this study, pilots exposed to aircraft noise were found to be at risk of having hypertension. This finding is supported by others. ${ }^{6,7,9,10}$ Noise is postulated as a risk factor for the cardiovascular system. ${ }^{9}$ It is a stressor that activates the sympathetic and endocrine systems. Shortterm changes in circulation (including blood pressure, 
heart rate, cardiac output, and vasoconstriction) as well as in levels of stress hormones (including epinephrine, norepinephrine, and corticosteroids) due to persistent noise have been studied in experimental settings for many years. ${ }^{6,7}$ These autonomic responses are primarily normal physiological responses of the organism to its environment. But, as a stressor noise do not habituate, it is suspected of being contributive to the possible causes of multifactorial chronic diseases, particularly of cardiovascular diseases. ${ }^{6,9,10}$ From this, the hypothesis emerged that persistent noise stress increases the risk of cardiovascular disorders including high blood pressure and ischemic heart disease.

Furthermore, our study showed that pilots with a higher resting pulse rate were more than 2 times likely to be at risk of hypertension, whereas pilots with a pulse pressure of more than $40 \mathrm{mmHg}$ were 2.3 times likely to be at risk of hypertension. This may be a reflection of stimulated sympathetic nervous and endocrine systems brought about by chronic exposure to noise. Chronic increase of sympathetic nervous system and adrenal hormones, such as norepinephrine will lead to a heightened peripheral resistance, which will in turn cause high blood pressure. ${ }^{9,10}$ This finding may strengthen the postulate that noise is a stressor that affect the cardiovascular system by activating the sympathetic and endocrine systems.

Pilots, in the course of their work, are constantly exposed to various noise generated by their respective aircrafts. The noise generated by these aircrafts may exceed $100 \mathrm{~dB}$, inside as well as outside the aircraft. ${ }^{18}$ Helicopters pilots are more at risk since the noise level is much higher and is compounded by vibration. ${ }^{17}$ This may be the reason why in our study, helicopter pilots were found to be almost 2 times more likely to develop hypertension compared to fixed wing pilots.

This was also true of pilots with a greater total flight hours. Our study showed that those with more than 1400 hours of flying time were almost 2 times more likely to develop hypertension compared to pilots with 1400 flight hours or less. These pilots were exposed to noise for a longer period of time. This would support a dose dependent relationship. A Japanese study on the association between blood pressure and aircraft noise exposure in Okinawa also found a dose dependent relationship. ${ }^{2}$

A limitation of the study was that the source of the data was records of mandatory annual medical examinations 2003 - 2008. However the examinations followed the rigid instructions of the standardized Technical Guidelines for Medical Tests and Examinations of the Indonesian Air Force pilots to which pilots may be grounded if the findings were not up to standards. ${ }^{13}$

In conclusion, aircrafts are a source of chronic noise for pilots and may be a risk factor for developing hypertension. Helicopter pilots had a greater risk of hypertension than fixed wing pilots. Increased total flight hours also increased the risk of hypertension.

\section{Acknowledgments}

The author wishes to thank the LAKESPRA Institute for making this study possible.

\section{REFERENCES}

1. World Health Organization. Guidelines for community noise. Geneva: The Organization; 2000.

2. Matsui T, Miyakita T. Association between blood pressure and aircraft noise exposure around Kadena airfields in Okinawa. The 2001 International Congress and Exhibition on Noise Control Engineering. The Hague: The Netherlands; 2001.

3. European Centre for Environment and Health Bonn Office. WHO technical meeting on aircraft noise and health. Bonn: WHO Regional Office for Europe; 2001

4. European Centre for Environment and Health Bonn Office. WHO technical meeting on noise and health indicators: second meeting - results of the testing and piloting in Member States. Bonn: WHO Regional Office for Europe; 2003.

5. Gonzalez JG, editor. Environmental noise main focus: aircraft noise. Bad Neuenahr-Ahrweiler: Europäische Akademie zur Erforschung von Folgen wissenschaftlichtechnischer Entwicklungen; 2004.

6. Babisch W, Ising H, Gallacher JEJ. Health status as a potential effect modifier of the relation between noise annoyance and incidence of ischaemic heart disease. Occup Environ Med. 2003;60:739-45.

7. Rosenlund M, Berglind N, Pershagen G, Järup L, Bluhm G. Increased prevalence of hypertension in a population exposed to aircraft noise. Occup Environ Med. 2001;58:76973.

8. Järup L, Dudley M-L, Babisch W, Houthuijs D, Swart W, Pershagen G, et al. Hypertension and exposure to noise near airports (HYENA): study design and noise exposure assessment. Environ Health Perspect. 2005;113:1473-8.

9. Oparil S, Weber M. Hypertension: companion to Brenner \& Rector's the kidney. 2nd ed. Philadelphia: Elsevier Saunders; 2005 .

10. Kaplan MN. Kaplan's clinical hypertension. 9th ed. Philadelphia: Lippincott Williams \& Wilkins; 2006.

11. Tomei F, De Sio S, Tomao E, Anzelmo V, Baccolo TP, Ciarocca $\mathrm{M}$, et al. Occupational exposure to noise and hypertension in pilots. Int J Environ Health Res. 2005;15:99106.

12. Siagian M, Basuki B, Kusmana D. High intersity interior aircraft noise increases the risk of high diastolic blood pressure in Indonesia Air Force pilots. Med J Indones. 2009; 18:276-82.

13. Joint National Committee on Prevention Detection, Evaluation, and Treatment of High Blood Pressure. The seventh report of the joint national committee on prevention, detection, evaluation, and treatment of high blood pressure. JAMA. 2003;289:2560-72.

14. Tentara Nasional Indonesia; Markas Besar Angkatan Udara. 
Buku petunjuk teknis TNI AU tentang uji dan pemeriksaan kesehatan. Jakarta (RI): TNI AU; 2007. Indonesian.

15. Stata Corp. Stata Statistical Software: Release 9.0. Getting started with Stata for Windows. Texas: Stata Corporation; 2007.

16. Breslow NE, Day NE. Statistical methods in cancer research: Volume I: The analysis of case-control studies.
IARC Sci Publ No.32. Lyon: International Agency for Research on Cancer; 1980.

17. Hosmer DW, Lemeshow S. Applied logistic regression. New York: John Wiley \& Sons; 1989.

18. Dinas Kesehatan TNI AU (RI). Hasil survey kebisingan dan vibrasi oleh Diskesau. Jakarta: Lakespra; 2005. Indonesian. 